\title{
非経験的分子軌道法を用いた窒化物セラミックス薄膜形成 における窒素分子と金属との反応解析*
}

\author{
平野 均** 遠藤勝義 $* *$ 堂本洋一** 蔵本慶一** \\ 木山精一** 津田信哉 ${ }^{\dagger} \quad$ 中野昭一 $^{\dagger}$
}

\begin{abstract}
Reaction Analysis of Nitrogen Molecules and Metals in the Fabrication of the Nitride Ceramic Thin Film using ab initio Molecular Orbital Method
\end{abstract}

Hitoshi Hirano, Katsuyoshi Endo, Yoichi Domoto, Keiichi Kuramoto,

Seiichi Kiyama, Shinya Tsuda and Shoichi NaKano

In a nitride ceramic thin film, the fabrication of $\mathrm{AlN}$ and $\mathrm{ZrN}$ thin films was attempted by an Ar ion beam sputtering method. The $\mathrm{ZrN}$ thin film was fabricated by sputtering a $\mathrm{Zr}$ target in a nitrogen atmosphere, while the $\mathrm{Al}$ and nitrogen reaction required the bombardment of nitrogen ions. Fabrication for both was based on the reaction between nitrogen and $\mathrm{Al}$ or $\mathrm{Zr}$ atoms. Accordingly, clarifying the difference in reactions between nitrogen and $\mathrm{Al}$ or $\mathrm{Zr}$ required a theoretical analysis by an ab initio molecular orbital method. An ab initio molecular orbital method was used to analyze the reaction of nitrogen molecules to $\mathrm{Al}$ atoms or to $\mathrm{Zr}$ atoms. According to the method, the bond order of nitrogen atoms may decrease when they are approached by $\mathrm{Zr}$ atoms, while the bond order may change little when the nitrogen atoms are approached by $\mathrm{Al}$ atoms. The results of calculations indicated that nitrogen molecules react to $\mathrm{Zr}$ atoms more actively than to $\mathrm{Al}$ atoms.

Key words: nitride ceramic thin film, aluminum nitride thin film, zirconium nitride thin film, reaction, electron state, ab initio molecular orbital method, atomic charge, bond order

\section{1. 緒 言}

近年の工業技術の発展に伴い，その基礎となる材料に対する 高機能化の要求はますをす強くなっている. 高機能材料は, 機 械, 電子, 航空宇宙等のあらゆる産業分野で開発が行われて拉 り，今後ますます発展するものと考学られる.

このよらな高機能材料において, 窒化物セラミックスは表面 コーティング材料, 電子デバイス材料, 耐熱材料, 光学材料等 への応用が期待され, 薄膜化することによりその用途は飛躍的 に増加する.

窒化物セラミックス薄膜の形成においては，その基礎となる のは $\mathrm{N}$ と窒化物セラミックス薄膜を構成する元素との反応で あるが, $\mathrm{N}_{2}$ 分子はその解離エネルギーが $9.76 \mathrm{eV}$ と等核二原 子分子の中で最大であり ${ }^{1)}$, 非常に不活性である. そのため, $\mathrm{N}_{2}$ 分子との自然反応により窒化物セラミックス薄膜を形成す るのは困難である場合が多い.したがって, 窒化には $\mathrm{NH}_{3}$ 等 が用いられることもあるが2), 過度の反応性の制御や水素の取 込み等が問題になることがある.

筆者らは, 压電材料, 放熱材料として期待される窒化アルミ ニウム $(\mathrm{AlN})$ 薄膜 ${ }^{334)}$ および表面保護材料, 耐熱材料として期 待される窒化ジルコニウム $(\mathrm{ZrN})$ 薄膜 ${ }^{5)}$ の低温形成に関する 検討を行ってきた. これらの $\mathrm{AlN}$ 薄膜, $\mathrm{ZrN}$ 薄膜形成は $\mathrm{N}$ （分子，イオン等）と $\mathrm{Al}$ 扣よび $\mathrm{Zr}$ との直接反応に基づくもの で反応の活性度を制御することが重要となる. しかし，これま で窒化物セラミックス薄膜形成に招いて, 金属と $\mathrm{N}_{2}$ 分子との 化学的な反応に関する理論的考察を行った報告はほとんどな

* 原稿受付 平成 7 年 11 月 27 日

** 正 会 員 三洋電機(株) (守口市京阪本通 2-5-5)

*** 正 会 員 大阪大学大学院工学研究科 (吹田市山田丘 2-1)

† 三洋電機(株)
W.

量子化学の分野では，化学反応が原子間結合の生成あるいは 消隇のプロセスであり，そのプロセスには電子が大きく関与す るため, 量子力学によって原子や分子の化学反応過程の解析が 行われている ${ }^{6)}$.さらに, 加工の分野でも加工現象を理解する 上で, 量子力学を利用しなければならない加工法も開発されて いる7). 今後, 薄膜材料形成に执いても新物質を創造するため には量子力学に基づく理論解析が重要になると考えられる.

化学反応の解析においては電子構造を計算する必要がある が, この計算が可能な方法として分子軌道 (Molecular Orbital：MO）法があり ${ }^{6)}, \mathrm{GaAs}$ 等の半導体材料の薄膜形成 プロセスでは分子軌道法を用いた理論解析が行われている ${ }^{8)}$.

そこで, 本報では窒化物セラミックスとして, AlN 薄膜, $\mathrm{ZrN}$ 薄膜を取り上げ, $\mathrm{N}$ と $\mathrm{Al}, \mathrm{Zr}$ との反応性の違いについて 実験的事実を述べるとともに, 非経験的（ab initio）分子軌道 法を用いて $\mathrm{N}_{2}$ 分子と $\mathrm{Al}$ 招よび $\mathrm{Zr}$ 原子との反応について理論 解析を行った結果について述べる.

\section{N と Al を用いた AIN 薄膜の低温形成}

\section{1 実験方法および条件}

$\mathrm{AlN}$ 薄膜の形成実験は, イオンビームスパッタ法により 行った. スパッタ用イオンガンより照射されたArイオンで直 径 5 インチの $\mathrm{Al}$ ターゲットをスパッタし, $\mathrm{Si}$ 基板上に薄膜を 形成した. この時, チャンバ内への $\mathrm{N}_{2}$ ガスの導入, またはつ シスト用イオンガンからの加速電圧 $100 \mathrm{~V}$ 程度の低ェネル ギーの N イオン照射を行った.

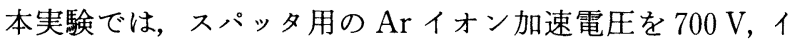
オン電流密度を $3.7 \mathrm{~mA} / \mathrm{cm}^{2}$ とした. チャンバ内に導入する $\mathrm{N}_{2}$ 分王は 4 $7 \times 10^{-2} \mathrm{~Pa}$ とした. また, 薄膜形成時に照射す る $\mathrm{N}$ イオンのイオン電流密度は $0.17 \mathrm{~mA} / \mathrm{cm}^{2}$ とした. $\mathrm{N}$ イ 


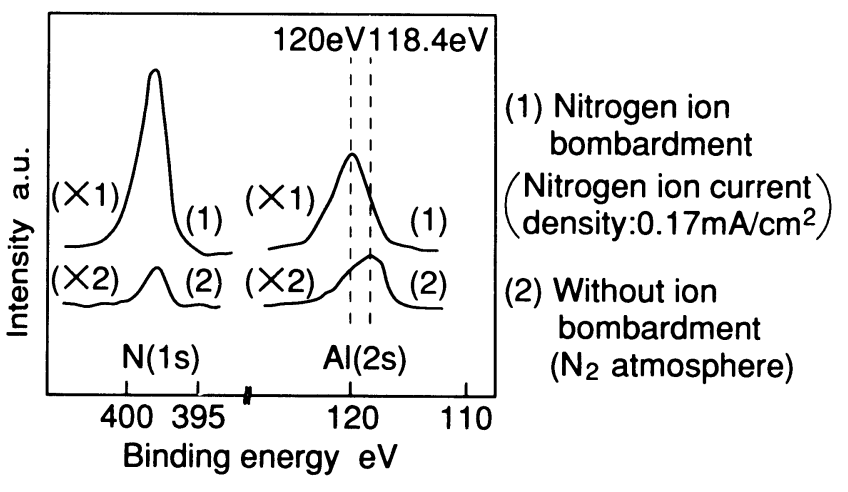

Fig. 1 Effect of nitrogen ion irradiation on fabrication of AlN thin film

オンの加速電圧に関しては, 反応性スパッタ法による $\mathrm{AlN}$ 薄 膜形成に怙いて, 高ェネルギー粒子の衝撃により薄膜の結晶 性, 配向性が悪化することから ${ }^{9)}, \mathrm{N}$ イオン加速電圧は小さい ほうが結晶性に与える影響は少ないと考えられる。しかし，加 速電圧が $100 \mathrm{~V}$ 未満では得られるイオン電流密度は小さいた め, 本研究では $100 \mathrm{~V}$ とした。な报, イオン電流密度の測定 にはファラデーカップを用い, 基板温度は室温とした。

このように, 本方法は $10^{-2} \mathrm{~Pa}$ 台の高真空中における低温形 成が可能であり，イオンビームの独立した制御により膜形成で きるため基礎的現象を把握するのに適した方法である.

\section{2 実験結果}

スパッタされた $\mathrm{Al}$ と $\mathrm{N}$ との反応性を調べるため, $\mathrm{N}_{2}$ 雾囲 気中で $\mathrm{Al}$ をスパッタして形成した薄膜と $\mathrm{Al}$ のスパッタと同 時にNイオンを照射して形成した薄膜の ESCA 分析を行っ た.

図 1 に(1) $\mathrm{Al}$ のスパッタと同時にNイオンを照射して形成 した薄膜と (2) $\mathrm{N}_{2}$ 雾囲気中で $\mathrm{Al}$ をスパッタして形成した薄 膜の ESCA 分析結果を示す. (1) の場合は, $\mathrm{Al}(2 \mathrm{~s})$ の結合エ ネルギーのピークが約 $118 \mathrm{eV}$ から約 $120 \mathrm{eV}$ に化学シフトす

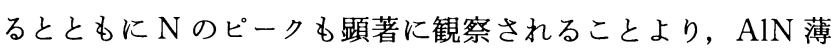
膜が形成されていることがわかる. これに対し，(2)の場合 は, $\mathrm{Al}(2 \mathrm{~s})$ のピークの化学シフトが見られず, $\mathrm{Al}$ が窒化され ていないことがわかる.

以上より, $\mathrm{Al}$ と $\mathrm{N}_{2}$ 分子との反応性は低く, 室温レベルで の AlN 薄膜の低温形成に関しては, $\mathrm{N}_{2}$ 分子をイオン化して照 射することが重要であり, 活性なイオンが反応促進に寄与する ことを確認できた.

\section{3. $\mathrm{N}$ と $\mathrm{Zr}$ を用いた $\mathrm{ZrN}$ 薄膜の低温形成}

\section{1 実験方法および条件}

$\mathrm{ZrN}$ 薄膜の形成も AlN 薄膜の場合と同様イオンビームス パッタ法により行った. 直径 5 インチの Zr ターゲットを使用 し, 真空チャンバ内に $\mathrm{N}_{2}$ ガスを導入し， $\mathrm{N}_{2}$ 雾囲気中でス パッタ用イオンガンから照射された Arイオンによって Zr ターゲットをスパッタし，Si 基板上に薄膜を形成した。

成膜条件は，スパッタ用イオンガンから照射される Arイオ ンの加速電圧は $700 \mathrm{~V}$, イオン電流密度は $3.7 \mathrm{~mA} / \mathrm{cm}^{2}$ とし た. 真空チャンバ内に導入される $\mathrm{N}_{2}$ 分王は, $0 \sim 1.9 \times 10^{-2} \mathrm{~Pa}$ の範囲で变化させた. なお, A1N 薄膜形成の場合と同様イオ ン電流密度の測定にはファラデーカップを用い, 基板温度は室 温とした。

\section{2 実験結果}

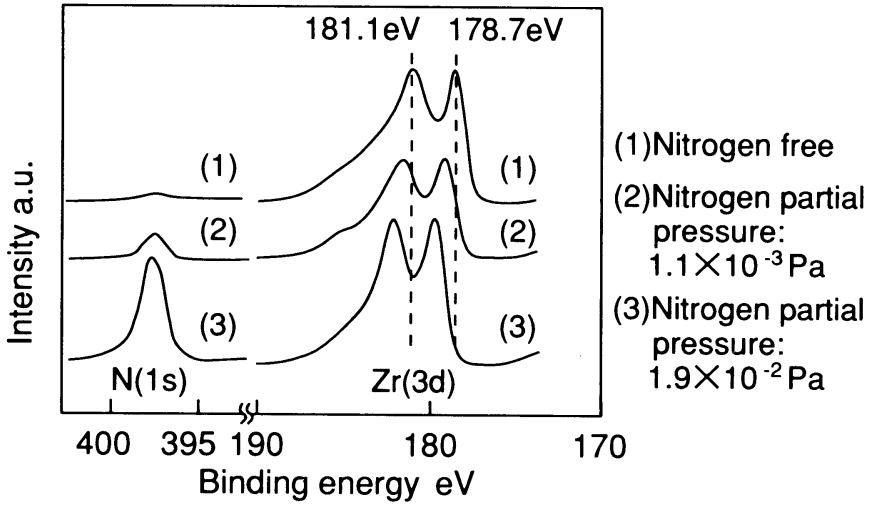

Fig. 2 ESCA spectra of $\mathrm{Zr}$ and $\mathrm{ZrN}$ thin films

真空チャンバ内に $\mathrm{N}_{2}$ ガスを導入せず形成した薄膜と $\mathrm{N}_{2}$ 分 圧を $1.1 \times 10^{-3} \mathrm{~Pa}, 1.9 \times 10^{-2} \mathrm{~Pa}$ の条件で形成した薄膜の ESCA 分析を行った結果を図 2 に示す.（1）の $\mathrm{N}_{2}$ ガスを導入 しない場合は $\operatorname{Zr}(3 \mathrm{~d})$ のつのピークは $178.7 \mathrm{eV}, 181.1 \mathrm{eV}$ の位置にあり, 化学シフトしていない. ところが, (2), (3) の ように $\mathrm{N}_{2}$ 分圧が増加するのに従いピークは高エネルギー側に 化学シフトし, また Nのピークに関しても（3）に招いて顕著 に観察されている. このことから，(3) の条件で ZrN が形成 されていることがわかっだ ${ }^{10)}$.

以上ょり， $\mathrm{Zr}$ と $\mathrm{N}$ との応は $\mathrm{Al}$ と $\mathrm{N}$ との反応とは異な り, $\mathrm{Zr}$ は $\mathrm{N}_{2}$ 分子との反応性が高く, イオン化しない $\mathrm{N}_{2}$ 分子 によっても容易に窒化されることが明らかとなった.

\section{4. 非経験的分子軌道法による $\mathrm{N}_{2}$ 分子と $\mathrm{Al}$ および $\mathrm{Zr}$ 原子との反応解析}

前章までに $\mathrm{AlN}$ 扎よび $\mathrm{ZrN}$ の各薄膜に打ける $\mathrm{N}$ と $\mathrm{Al}, \mathrm{Zr}$ との反応性の違いに関する実験的事実について述べたが，この 反応性の違いを理論的に解析することは, 薄膜の膜質向上, 低 温化を目的とした最適形成法を確立する上で重要である.

\section{1 非経験的分子軌道法による電子状態計算の概要}

緒言でも述べたように, 分子の電子状態を取り扱ら量子力学 的手法の一つに分子軌道法がある ${ }^{6)}$. 分子軌道法とは, 複数個 の原子から構成される分子において，それぞれの原子核を包み 込む軌道, すなわち分子軌道を仮定し, 原子に属する電子をこ の分子全体に広がる分子軌道に割り当て電子の状態を求め, そ れらを用いて分子の諸性質を論じる方法である.

非経験的分子軌道法によれば11)，2n個の電子を持つ分子の 系全体の波動関数 $\Psi$ は式 (1) のようにスレーターの行列式で 表される.

$$
\Psi=\frac{1}{\{(2 n) !\}^{1 / 2}}\left\|\cdots \phi_{i} \alpha \phi_{i} \beta \cdots\right\|
$$

ここで， $\phi_{i}$ は分子に打ける個々の分子軌道， $\alpha, \beta$ はスピンの 種類を表す.

さらに, Hartree-Fock 近似に基づく一電子波動方程式は, 変分法により, 以下のように導出される.

$$
\begin{aligned}
& F(1) \phi_{i}(1)=\varepsilon_{i} \phi_{i}(1) \\
& F(1)=-\left(\frac{h^{2}}{8 \pi^{2} m_{\mathrm{e}}}\right) \nabla_{1}{ }^{2}+V(1)+V^{\mathrm{HF}}(1) \\
& V(1)=\sum_{A=1}^{L}\left(\frac{-Z_{A} e^{2}}{r_{A 1}}\right)
\end{aligned}
$$

ここで, $F(1)$ は Fock 演算子と呼ばれる一電子演算子 ${ }^{11)}, \varepsilon_{i}$ 


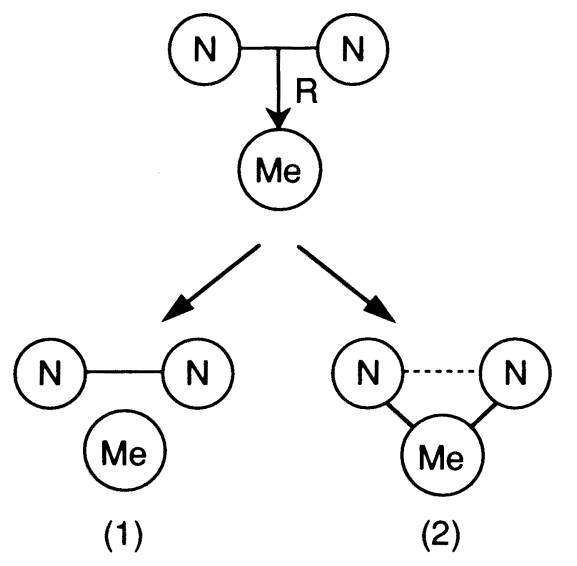

Fig. 3 Model of reaction analysis

は分子軌道の $i$ 番目の軌道エネルギーを表す. $h$ はプランク定 数, $m_{\mathrm{e}}$ は電子の質量で, 式 (3) の第 1 項は電子 1 の運動エネ ルギーを表す， $V(1)$ は分子を構成している $L$ 個の原子の原 子核による電子 1 のポテンシャル, $V^{\mathrm{HF}}(1)$ は他の電子による 電子 1 の平均ポテンシャル, $r_{A 1}$ は $A$ 番目の核と 1 番目の電 子の距離, $Z_{A}$ は $A$ 番目の原子の原子番号である.

上記の $\phi_{i}$ は LCAO MO 法 ${ }^{11)}$ に基づき, 既知の原子軌道の 線形結合として,

$$
\phi_{i}=\sum_{r=1}^{m} C_{i r} \chi_{r}
$$

で与えられる.

ここで, $m$ は分子を構成している原子軌道の総数, $C_{i r}$ は各 原子軌道の係数， $\chi_{r}$ は原子軌道である.

本報では, 原子軌道すなわち基底関数として複数個のガウス 型関数の線形結合によって置き換えたものを用いた。 ガウス型 軌道はスレーター型軌道に比べて積分が著しく簡単になるため 計算時間が大幅に短縮されるといら特長がある ${ }^{12)}$. また, 式 (2)の $\varepsilon_{i}$ および式 (5)の $C_{i r}$ は SCF 法 ${ }^{11)} に よ り$ 求めた.

\section{$4.2 \mathrm{~N}_{2}$ 分子と $\mathrm{Al}$ および $\mathrm{Zr}$ 原子との反応解析モデル}

イオンビームスパッタによる金属と $\mathrm{N}_{2}$ 分子との反応に基づ く窒化物セラミックス薄膜形成に扣いて, $\mathrm{N}_{2}$ 分子と $\mathrm{Al}$ のよ らに反応性の低い金属の場合には, $\mathrm{N}_{2}$ 分子とは反応せず基板 上にその金属薄膜が形成されるが， $\mathrm{Zr}$ のように $\mathrm{N}_{2}$ 分子と反応 性の高い金属の場合には，基板上に窒化物が形成される.

このような反応を論じる場合，その基礎となるのは金属原子 と $\mathrm{N}_{2}$ 分子との反応である. そこで, 金属原子 $(\mathrm{Me})$ と $\mathrm{N}_{2}$ 分 子からなる仮想分子 $\mathrm{Me}^{-} \mathrm{N}_{2}$ を考学る. 図 3 に基礎的モデルす なわち反応解析モデルを示す. $\mathrm{N}_{2}$ 分子と金属原子との反応性 の違いにより， $\mathrm{N}_{2}$ 分子が金属原子に接近した時に $\mathrm{N}$ 原子どら しの結合の変化に差が見られると考えられる. (1) の $\mathrm{N}_{2}$ 分子 と反応性の低い金属の場合には, $\mathrm{N}_{2}$ 分子が金属原子に近づい ただけでは $\mathrm{N}_{2}$ 分子は解離せず, 解離反応を引き起こして窒化 物を形成するためには何らかのエネルギーのアシストが必要と 考兄られ. 一方，（2）の $\mathrm{N}_{2}$ 分子と反応性の高い金属の場合 には, $\mathrm{N}_{2}$ 分子が金属原子に接近しただけで $\mathrm{N}_{2}$ 分子は解離す ると考えられる.

このようなモデルに基づく $\mathrm{N}_{2}$ 分子と金属原子との反応解析 は, 非経験的分子軌道法により可能になる. この方法により, $\mathrm{N}_{2}$ 分子と金属原子から構成される仮想分子の分子軌道を求め, さらに, Atomic charge, Bond orderを求めるためのポピュ
レーション解析を行らことにより, 量子力学に基づく詳細な反 応解析が可能となる ${ }^{13)}$.

本報では，上記モデルに基づき $\mathrm{N}_{2}$ 分子と $\mathrm{Al}$ および $\mathrm{Zr}$ 原子 との反応性について解析を行う。

\section{3 計算結果}

計算は非経験的分子軌道法プログラムである $\operatorname{AMOSS}(\mathrm{Ab}$ initio Molecular Orbital System for Supercomputers：日本電 気(株)製)を用いてスーパコンピュータにより行った. 分子軌 道計算には有効内殼ポテンシャル (Effective Core Potential : $\mathrm{ECP})$ 法を用いた. この方法は, 原子の一番外側の原子価殸 にある電子のみが化学結合に直接関与するという原子価概念に 基づくものであり, 基底関数としては内殼電子を省略すること ができるので計算時間が短縮できるといら特長がある ${ }^{14) 15}$. 従って, 取り扱ら電子は, $\mathrm{Al}$ 原子では $(3 \mathrm{~s})^{2}(3 \mathrm{p})^{\mathrm{1}}$ の 3 個, $\mathrm{Zr}$ 原子では $(4 \mathrm{~d})^{2}(5 \mathrm{~s})^{2}$ の 4 個, $\mathrm{N}$ 原子では $(2 \mathrm{~s})^{2}(2 \mathrm{p})^{3}$ の 5 個で ある.

また, 基底関数には分子中の化学結合をより厳密に表現する ために, $\mathrm{Al}$ 原子に $3 \mathrm{~d}, \mathrm{Zr}$ 原子に $5 \mathrm{p}, \mathrm{N}$ 原子に $3 \mathrm{~d}$ の分極関数 を追加した ${ }^{12)}$.さらに, 計算は制限開殼 Hartree-Fock 法で行 い, 図 3 のモデルにおける $\mathrm{N}$ 原子間距離を $0.109 \mathrm{~nm}, \mathrm{~N}_{2}$ 分 子と金属原子との距離 $R$ をパラメータとし, 距離 $R$ を $0.1 \sim 0.2 \mathrm{~nm}$ の間で変化させ, 各距離 $R$ における分子軌道,

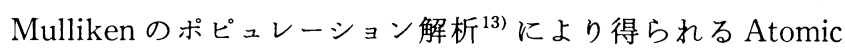
charge， $\mathrm{N}$ 原子間抢よび金属と $\mathrm{N}$ 原子間の Bond order を求 めた.

まず, $\mathrm{N}_{2}$ 分子と金属原子からなる $\mathrm{Al}-\mathrm{N}_{2}$ 分子拉よび $\mathrm{Zr}-\mathrm{N}_{2}$ 分子に扮ける分子軌道を求めた。本計算で取り扱ら電子数は $\mathrm{Al}-\mathrm{N}_{2}$ 分子で 13 個であり, エネルギーの低い方から 6 番目の 分子軌道までが 2 個の電子で占有され, 7 番目は 1 個の電子で 占有される開殼構造となる。 一方, $\mathrm{Zr}-\mathrm{N}_{2}$ 分子では取り扱う電 子数は 14 個であるが, 閉殸構造よりも開殼構造の方がェネル ギー的に安定するため, これも開殼 Hartree-Fock 法で計算す る. したがって, エネルギーの低い方から 6 番目の分子軌道ま で 2 個の電子で占有され， 7 番目， 8 番目の軌道は一電子占有 となる。

一例として，図 4 に $\mathrm{N}_{2}$ 分子と金属原子との距離 $R$ が 0.2 $\mathrm{nm}$ の時のエネルギーの低い方から $\mathrm{Al}-\mathrm{N}_{2}$ 分子では 6 番目 (No.6), 7 番目 (No. 7 : 最外殼軌道), $\mathrm{Zr}-\mathrm{N}_{2}$ 分子では 7 番目 (No. 7), 8 番目 (No. 8: 最外殼軌道) の分子軌道, 特よび分 子軌道を構成する原子軌道の中で最も顕著な原子軌道を示す. ここで, 分子軌道に持ける赤, 青色はそれぞれ波動関数の位相 を示す。

$\mathrm{Al}-\mathrm{N}_{2}$ 分子の No. 6 では図に示される分子軌道に拈いて N 原子と $\mathrm{Al}$ 原子の波動関数の間に交わりがなく, $\mathrm{Al}$ 原子と $\mathrm{N}$ 原子は強く結合していない，これは，この分子軌道を構成して いる原子軌道の中で最も顕著な原子軌道である $\mathrm{Al}$ 原子の $3 \mathrm{~s}$ 軌道と $\mathrm{N}$ 原子の $2 \mathrm{p}$ 軌道が反結合性軌道であるためと考えられ る. No. 7 では $\mathrm{Al}$ 原子の $3 \mathrm{p}$ 軌道と $\mathrm{N}$ 原子の $2 \mathrm{p}$ 軌道は結合性 軌道であり，分子として結合していることがわかる.

一方, $\mathrm{Zr}-\mathrm{N}_{2}$ 分子の場合は $\mathrm{N}$ 原子の $2 \mathrm{p}$ 軌道と $\mathrm{Zr}$ 原子の $4 \mathrm{~d}$ 軌道が相互作用し, No. 7, No. 8 はともに $\mathrm{N}$ 原子の $\mathrm{p}$ 軌道と $\mathrm{Zr}$ 原子の d 軌道からなる結合性軌道であり, 波動関数から判 断して, $\mathrm{N}$ 原子と $\mathrm{Zr}$ 原子は強く結合していることがわかる.

ところが, $\mathrm{N}_{2}$ 分子に着目すると $\mathrm{Zr}-\mathrm{N}_{2}$ 分子ではNo. 7, No. 8 の軌道で反結合性の $\pi$ 結合に電子が入ることによる（電 

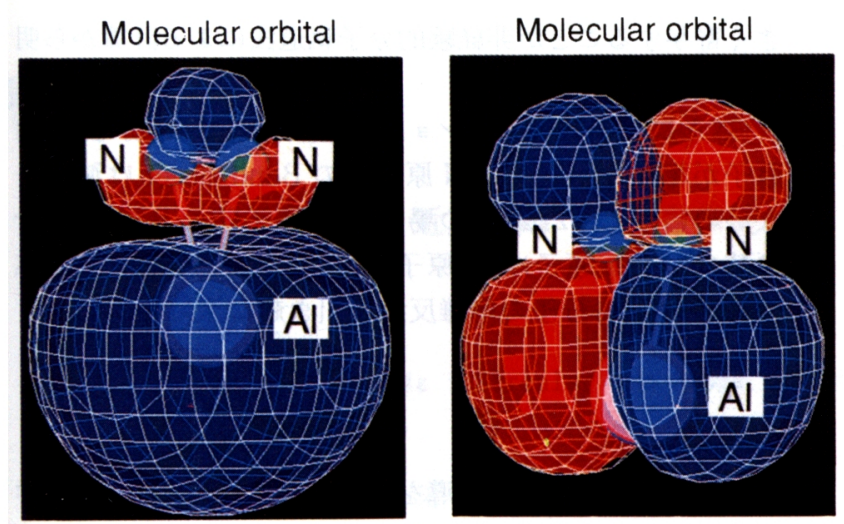

Atomic orbital

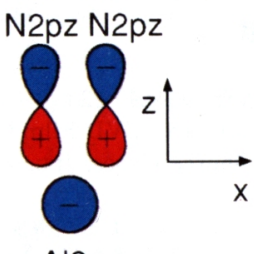

Al3s

No.6
Atomic orbital

$\mathrm{N} 2 \mathrm{pz} \mathrm{N} 2 \mathrm{pz}$

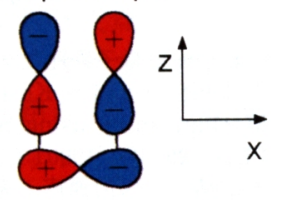

$\mathrm{Al} 3 \mathrm{px}$

No.7

(a) Al- $\mathrm{N}_{2}$ molecule

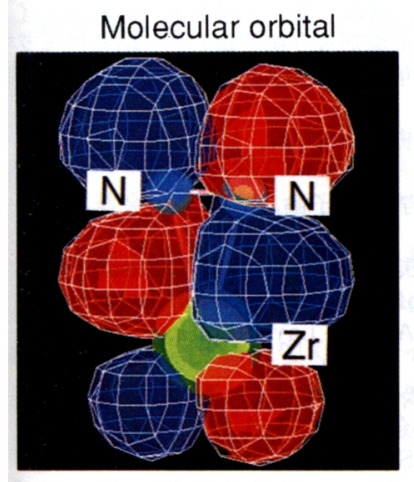

Atomic orbital

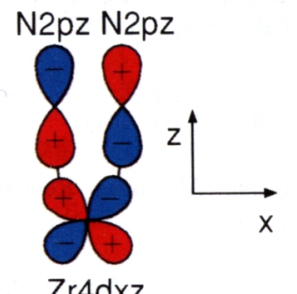

No.7

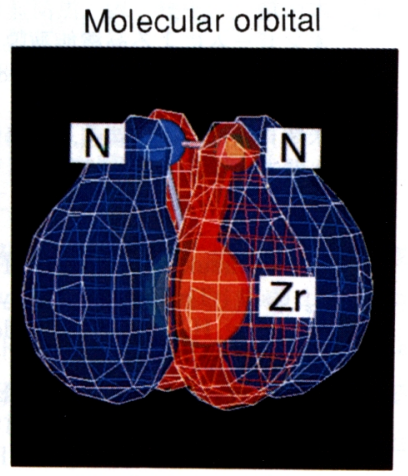

Atomic orbital

N2py N2py

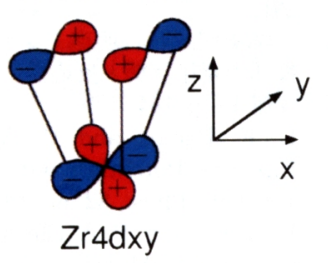

No.8

(b) $\mathrm{Zr}-\mathrm{N}_{2}$ molecule

Fig. 4 Interaction of atomic orbital

子の逆供与) $\mathrm{N}$ 原子間の結合の弱まりが見られる. 距離 $R$ を $0.1 \sim 0.2 \mathrm{~nm}$ の範囲で変化させた時の各分子軌道について見る と, 上記と同様, $\mathrm{N}$ 原子と最も強く相互作用する軌道は $\mathrm{A} 1$ 原 子の場合は $\mathrm{s}, \mathrm{p}$ 軌道であるのに対し, $\mathrm{Zr}$ 原子の場合はほとん どが $\mathrm{d}$ 軌道であった. このように, $\mathrm{Zr}$ 原子と $\mathrm{N}_{2}$ 分子が結合 した時の $\mathrm{N}_{2}$ 分子の解離反応の本質は, $\mathrm{N}$ 原子と $\mathrm{Zr}$ 原子が結 合した場合に, $\mathrm{Zr}$ 原子の $\mathrm{d}$ 軌道が作用することで $\mathrm{N}_{2}$ 分子の 反結合性の $\pi$ 結合に電子が入るため, $\mathrm{N}$ 原子間の結合が弱ま ることである.

以上のように, $\mathrm{N}_{2}$ 分子の解離反応過程には $\mathrm{d}$ 軌道が大きく 寄与する.

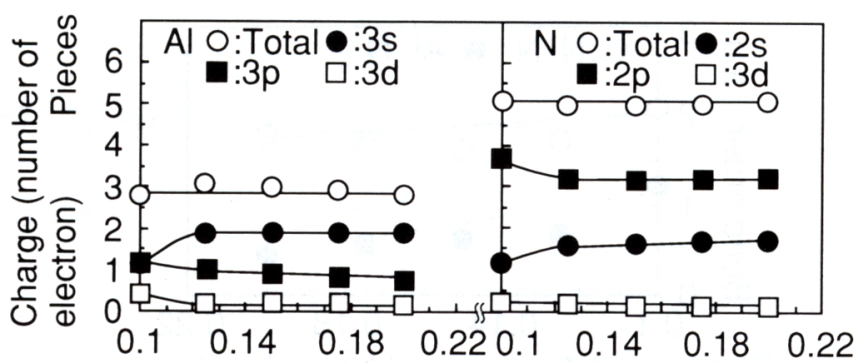

Distance of $\mathrm{Al}$ atom and $\mathrm{N} 2$ molecule $\mathrm{nm}$

(a) $\mathrm{Al}-\mathrm{N}_{2}$ molecule

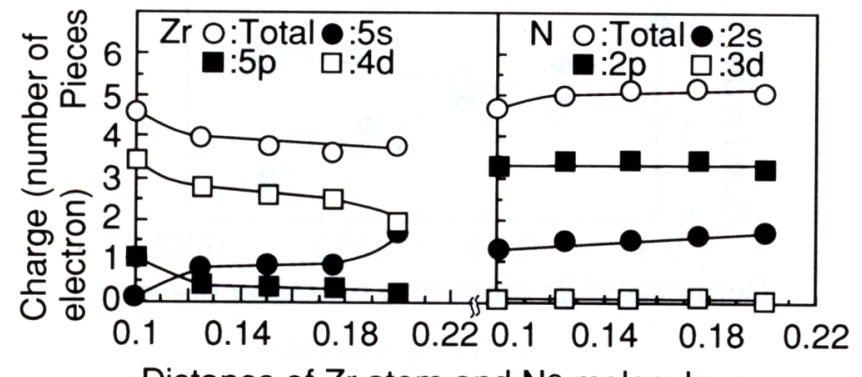

Distance of $\mathrm{Zr}$ atom and $\mathrm{N} 2$ molecule $\mathrm{nm}$

(b) $\mathrm{Zr}-\mathrm{N}_{2}$ molecule

Fig. 5 Relationship between charge and distance $R$

そこで, $\mathrm{N}_{2}$ 分子と $\mathrm{Al}$ 蛙よび $\mathrm{Zr}$ の各原子との反応につい て, 定量的に解析をするため Mullikenのポピュレーション解 析を行った.

図 5 には $\mathrm{N}_{2}$ 分子と $\mathrm{Al}$ 抢よび $\mathrm{Zr}$ 原子との距離 $R$ が変化し た時の $\mathrm{N}$ 原子， $\mathrm{Al}$ 原子， $\mathrm{Zr}$ 原子の各原子軌道の Charge おょ びトータルの Charge を示す. 本計算で扱ら電子数は $\mathrm{N}$ 原子 では 5 個， $\mathrm{Al}$ 原子では 3 個， $\mathrm{Zr}$ 原子では 4 個である. $\mathrm{Al}-\mathrm{N}_{2}$ 分子の場合は, 距離 $R$ が減少するのに従い $\mathrm{Al}$ 原子と $\mathrm{N}$ 原子 の $\mathrm{s}$ 軌道の Charge は減少し, p, d 軌道の Charge は増加する が, トータルの Charge はともに変化がない. それに対して, $\mathrm{Zr}-\mathrm{N}_{2}$ 分子の場合は, 距離 $R$ が減少するのに従い $\mathrm{Zr}$ 原子と $\mathrm{N}$ 原子の $\mathrm{s}$ 軌道の Charge は減少し, $\mathrm{Zr}$ 原子の $\mathrm{p}, \mathrm{d}$ 軌道の Charge は増加する. 特に, d 軌道の Charge は大幅に増加し て扣りトータルの Charge \& $\mathrm{N}$ 原子では約 5.1 から約 4.7 に減少し, $\mathrm{Zr}$ 原子では約 3.8 から約 4.6 に増加し, $\mathrm{N}$ 原子か ら Z r 原子への電子の移動があることがわかる.

このように電子の移動の面からも， $\mathrm{N}_{2}$ 分子に対して d 軌道 の作用により $\mathrm{Zr}$ の方が $\mathrm{Al}$ よりも反応性に富むことがわかっ た.

次に, $\mathrm{N}_{2}$ 分子と金属原子との距離 $R$ と $\mathrm{Al}-\mathrm{N}_{2}$ 分子拈よび $\mathrm{Zr}-\mathrm{N}_{2}$ 分子における Bond order の関係を図 6 に示す. Bond order はその值が大きい汪ど結合が強いことを示す。ここで, Bond order は, $\mathrm{N}$ 原子間拈よび $\mathrm{N}$ 原子と $\mathrm{Al}$ および $\mathrm{Zr}$ の各 原子との間の Bond order を示す. $\mathrm{Al}-\mathrm{N}_{2}$ 分子の場合には, 距 離 $R$ が減少しても $\mathrm{N}$ 原子間の Bond order は匡とんど変化せ

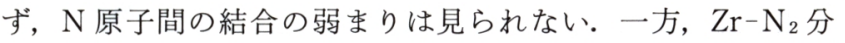
子の場合には, 距離 $R$ が減少するのに従い $\mathrm{N}$ 原子間の Bond order は減少し, 距離 $R$ が $0.1 \mathrm{~nm}$ の時の值は約 1.3 と $\mathrm{N}_{2}$ 分 子に和ける $\mathrm{N}$ 原子間の Bond order の約 2.7 に比べて半分以 下に低下して和り， $\mathrm{N}$ 原子間の結合が大幅に弱まることがわ かった。 また， $\mathrm{Zr}$ 原子と $\mathrm{N}$ 原子との間の Bond order は $\mathrm{Al}$ 原 


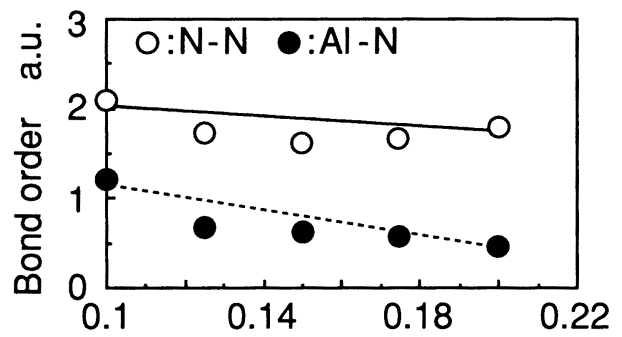

Distance of $\mathrm{Al}$ atom and $\mathrm{N} 2$ molecule $\mathrm{nm}$

(a) Al- $\mathrm{N}_{2}$ molecule

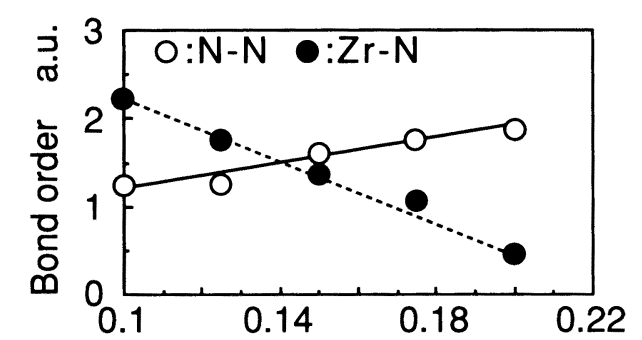

Distance of $\mathrm{Zr}$ atom and $\mathrm{N} 2$ molecule $\mathrm{nm}$

(b) $\mathrm{Zr}-\mathrm{N}_{2}$ molecule

Fig. 6 Relationship between bond order and distance $R$

子と $\mathrm{N}$ 原子との間の Bond order に比較して大幅に増加し, 距離 $R$ が $0.14 \mathrm{~nm}$ 以下では $\mathrm{Zr}$ 原子と $\mathrm{N}$ 原子との結合が $\mathrm{N}$ 原 子間の結合よりも強くなり, これらのことより， $\mathrm{N}_{2}$ 分子は明 らかに解離する方向にあることがわかった.

以上のことより，非経験的分子軌道法による計算結果から も, d 軌道の作用により $\mathrm{Zr}$ 原子は $\mathrm{Al}$ 原子と比較して明らかに $\mathrm{N}_{2}$ 分子との反応性は高く, $\mathrm{N}_{2}$ 分子の解離反応を引き起こすこ とが確認され，実験結果との良い対応を示した.

\section{5. 結言}

イオンビームスパッタにより窒化物セラミックスの一種であ る $\mathrm{AlN}$ 薄膜, $\mathrm{ZrN}$ 薄膜の低温形成実験を行い, $\mathrm{N}$ と $\mathrm{Al}, \mathrm{Zr}$ と の反応性の違いを明らかにするとともに，これらの反応につい て非経験的 (ab initio) 分子軌道法により理論解析を行い, 以 下の結論を得た.

（1） $\mathrm{Al}$ と $\mathrm{N}_{2}$ 分子との反応性は低く, $\mathrm{AlN}$ 薄膜形成には $\mathrm{N}$ のイオン化が重要であるのに対し, $\mathrm{Zr}$ と $\mathrm{N}_{2}$ 分子との反応 性は高く, $\mathrm{ZrN}$ 薄膜は $\mathrm{N}_{2}$ 雾囲気中での $\mathrm{Zr}$ のスパッタ蒸 着により形成可能であることが成膜実験および ESCA 分 析による化学シフトからわかった.

（2） $\mathrm{N}_{2}$ 分子と $\mathrm{Zr}$ 原子との反応には $\mathrm{Zr}$ 原子の $\mathrm{d}$ 軌道が大
きく寄与することが非経験的分子軌道法による計算から明 らかとなった。

（3）さらに，ポピュレーション解析によって $\mathrm{N}_{2}$ 分子と $\mathrm{Al}$ 原子が相互作用しても $\mathrm{N}$ 原子間の Bond order は減少し ないのに対し， Zr 原子の場合は $\mathrm{N}$ 原子間の Bond order は減少し, $\mathrm{Zr}$ 原子は $\mathrm{Al}$ 原子と比較して $\mathrm{N}_{2}$ 分子との反応 性は高く, $\mathrm{N}_{2}$ 分子の解離反応を引き起こすことがわかっ た.

\section{謝辞}

本研究に関して, 終始ご指導をいただきました大阪大学大学 院工学研究科森勇藏教授, 片岡俊彦教授に深く感謝致します.

\section{参 考 文 献}

1）大野公一：量子物理化学, 東京大学出版会, (1991) 223.

2) A. Ishitani and S. Koseki : A Model for $\mathrm{SiN}_{x}$ CVD Film Growth Mechanism by using $\mathrm{SiH}_{4}$ and $\mathrm{NH}_{3}$ Source Gases, Jpn. J. Appl. Phys., 29, 12, (1990) L 2322.

3）木山精一，黑河通広，大隅正人：イオンビームによる高機能薄膜の 低温形成 (第 1 報) 一一窒化アルミニウムの結晶性制御, 1989 年度 精密工学会春季大会学術講演会講演論文集, (1989) 1077.

4）木山精一，平野 均，堂本洋一，蔵本慶一，黒河通広，鈴木龍司， 大隅正人：低エネルギーイオンビーム照射による AlN 膜の低温形 成, 精密工学会誌, 60, 7 (1994) 1029.

5）木山精一, 平野 均, 黒河通広, 河田 宏, 大隅正人：アシストイ オンビームによる高機能薄膜の低温形成（第 2 報）—結晶性セラ ミックス膜形成の高速化，1989 年度精密工学会秋季大会学術講演会 講演論文集, (1989) 17 .

6) 米澤貞次郎, 永田親義, 加藤博史, 今村 詮, 諸能奎治 : 量子化学 入門, 化学同人, (1992) 4 .

7）森勇藏：これからの精密工学と電子論，精密工学会誌，59, 6 (1993) 5.

8) Y. Mochizuki, T. Takada, T. Sakuma, S. Handa, C. Sasaoka and A. Usui : Theoretical Study of the Cl Desorption Reaction Induced by $\mathrm{H}_{2}$ in the Chloride Atomic Layer Epitaxy, J. Crystal Growth, 135, (1994) 259.

9）松岡茂登, 星 陽一, 直江正彦：反応スパッタ法による $\mathrm{c}$ 軸配向 AlN 膜の高速形成, 電子通信学会論文誌, J 68-C, 7 (1985) 548 .

10) H. Höchst, R. D. Bringans, P. Steiner and Th. Wolf : Photoemission Study of the Electronic Structure of Stoichiometric and Substoichiometric TiN and ZrN, Phys. ReV., B 25, (1982) 7183.

11）大岩正芳：初等量子化学—その計算と理論，化学同人，(1993） 231.

12）小関史朗, 石谷明彦：シリコン CVD の理論的研究——シリレン置 換体の電子状態と反応性，応用物理，59, 8 (1990) 1014 .

13）文献 1), p. 144.

14) L. F. Pacios and P. A. Christiansen: Ab initio Relativistic Effective Potentials with Spin-orbit Operators. I. Li through Ar, J. Chem. Phys., 82, 6, (1985) 2664.

15) L. A. LaJohn, P. A. Christiansen, R. B. Ross, T. Atashroo and W. C. Ermler : Ab initio Relativistic Effective Potentials with Spinorbit Operators. III . Rb through Xe, J. Chem. Phys., 87, 5, (1987) 2812 . 